\title{
9. Birds from the Baynunah Formation
}

Antoine Louchart ${ }^{1}$, Faysal Bibi ${ }^{2}$ and John R. Stewart ${ }^{3}$

${ }^{1}$ CNRS, UMR 5276, LGL-TPE, ENS de Lyon and Université Lyon 1, Bât. Geode, 2 rue Raphaël Dubois, 69622 Villeurbanne Cedex, France antoine.louchart@ens-lyon.fr ${ }^{2}$ Museum für Naturkunde, Leibniz Institute for Evolution and Biodiversity Science, Invalidenstrasse 43, 10115 Berlin, Germany. ${ }^{3}$ Faculty of Science and Technology, Bournemouth University, Christchurch House, Talbot Campus, Poole, Dorset BH12 5BB, U.K.

\begin{abstract}
The late Miocene Baynunah Formation in western Abu Dhabi Emirate (United Arab Emirates) has yielded new bird fossils, including both skeletal and eggshell remains that we describe here, together with a revision and summary of previous findings. A ratite pelvis is characterized by its larger size compared with extant ostriches and is assigned to Struthio cf. karatheodoris. Fossil eggshells belong to the ootaxon Diamantornis laini as well as to an aepyornithoid type. Diamantornis laini is previously recorded from contemporaneous sites in Africa, and aepyornithoid eggshells are widespread across Neogene sites in Eurasia and Africa. Neognath birds are represented by three taxa, a cormorant Phalacrocorax sp. (size of P. fuscicollis), a darter Anhinga cf. hadarensis, and a heron of the tribe Nycticoracini. The darter attests to a link with Africa, being tentatively referred to a fossil species known from East Africa. The Baynunah birds provide valuable information on the biogeographic origins of different components of the avifauna in the late Miocene, near the junction between the Palaearctic, Indomalayan and Afrotropical zoogeographical regions.
\end{abstract}

Running head: Birds 


\section{Introduction}

The evolutionary history of birds in the Arabian Peninsula is poorly known due to a lack of abundant fossil collections. The region is important from a biogeographical point of view because, as part of the Saharo-Arabian zoogeographical region, it forms the boundary between the Afrotropical ('Ethiopian') and Palaearctic zoogeographical regions of the world (Holt et al. 2013), and this would have been the case in the late Miocene as well. Previous work has shown that the avifauna of the Baynunah Formation comprises freshwater taxa in the Anhingidae and Ardeidae families as well as large quantities of ratite eggshell fragments (Stewart and Beech 2006; Bibi et al. 2006; see also Whybrow \& Clements, 1999).

Recent excavations and paleontological survey work (Bibi et al. 2013; Bibi et al., this volumea) have recovered further avian fossil specimens from multiple localities of the Baynunah Formation (Fig. 9.1) and these are described here.

[FIGURE 9.1 NEAR HERE]

\section{Methods}

All Baynunah fossils are identified by the prefix AUH and all avian specimens are housed in Abu Dhabi under the authority of the Historic Environment Department of the Abu Dhabi Department of Culture and Tourism (see Bibi et al., this volume-a for further details), with the exception of a few fragments of Diamantornis laini eggshell curated at the Yale Peabody Museum under specimen number 56715. An unnumbered Anhinga coracoid (Stewart and Beech 2006, fig. 6) is currently at the Natural History Museum, London, pending its return to Abu Dhabi.

The following remains were identified by means of modern bird comparative material at the Natural History Museum at Tring in Hertfordshire, England (specimen numbers preceded by BM), the Laboratoire d'Anatomie Comparée of the Museum National d'Histoire Naturelle in Paris, France (LAC), the bird skeleton collection of the Université Lyon 1, Villeurbanne, France (UCBL-Aves), the Institut Royal des Sciences Naturelles de Belgique in Brussels, Belgium (IRSNB), the Ornithology collection at the American Museum of Natural History, New York (AMNH), and one specimen from 
the Pierce Brodkorb collection in Gainesville, Florida, USA (PB). The material used for comparative anatomical and measurement purposes included the following:

Ardeidae-Botaurus stellaris (BM 2008.13.1, UCBL-Aves-32.2); Ixobrychus minutus (UCBL-Aves31.1, 31.5 to 31.7); Nycticorax nycticorax (BM S/1988.67.1, UCBL-Aves-30.1 to 30.3); Nyctanassa violacea (UCBL-Aves, donated from Smithsonian collections, and labeled GEW5353); Ardeola ralloides (UCBL-Aves-28.1, 28.5); Bubulcus ibis (UCBL-Aves-29.1 to 29.3); Ardea cinerea (UCBLAves-24.1 to 24.4); Ardea purpurea (BM S/1973.66.24, UCBL-Aves-25.1 to 25.4); Egretta alba (BM S/1964.1.5); Egretta intermedia (BM S/1973.7.9); Egretta garzetta (UCBL-Aves-26.1 to 26.3). Phalacrocoracidae-Phalacrocorax aristotelis (UCBL-Aves-20.1 to 20.3); Phalacrocorax carbo (UCBL-Aves-19.1, 19.2). Anhingidae-Anhinga melanogaster (BM 1848.10.31.7); A. rufa (BM S/1952.1.87, IRSNB 12295, IRSNB 22452); A. rufa/melanogaster (LAC 1882.612, LAC 1883.543, LAC 1884.193, LAC 1886.176); A. anhinga anhinga (BM S/1974.11.1); Anhinga anhinga (BM 1896.2.16.17, LAC 1934.541, PB 22871); Anhinga sp. (BM S/1952.3.159). Ratitae - Struthio camelus (AMNH ornithology SKEL 965, SKEL 966, SKEL 1294, SKEL 1821). Pelvic specimens of other ratites were also examined in the AMNH collections, but specimen numbers were not noted (and no measurements were taken).

Anatomical description mainly follows Baumel and Witmer (1993). Taxonomic systematics follows the Handbook of the Birds of the World Alive (Del Hoyo et al. 2017). Detailed information on Baynunah fossil localities is given by Bibi et al. (this volume-a).

\title{
Systematic Paleontology
}

\author{
Palaeognathae Pycraft, 1900 \\ Ratitae Huxley, 1867 \\ Struthionidae Vigors, 1825 \\ Struthio Linnaeus, 1758
}

Struthio cf. S. karatheodoris Forsyth Major, 1888 
Material: AUH 1134, pelvis, almost complete with the exception of the pubic symphysis region. Excavated from a conglomerate at Kihal 2 (KIH 2-1). A mold and cast are deposited at the Yale Peabody Museum.

[FIGURE 9.2 NEAR HERE]

Description: All pelvic anatomical characters described here are illustrated in Figure 2. The pelvis is almost complete on both sides, missing only the pubic symphysis and the distal portions of the right pubis and ischium. As in extant Struthio camelus, AUH 1134 has six preacetabular pelvic vertebrae (PV), and four acetabular PV, with PV 8 and 9 fused together. The presence of fenestrations along the midline on the postacetabular dorsal surface of the pelvis is typical of S. camelus. In other ratites such as Rhea or Casuarius, for example, the iliac blades are well fused to the spinous processes all the way down the midline. The presence of a midline projection of the iliac blades at their cranial end ('dorsocranial protuberance' in Fig. 2) as well as fused ventral ribs on both PV 1 and 2 are also similar to $S$. camelus and unlike other ratites. Rheas (Rhea and Pterocnemia), which are the most osteologically similar ratites to Struthio, have a large PV 1 rib, but no PV 2 rib, and specimens of Casuarius observed had no PV ribs attached. The left and right ridges on the ventral surface of the centra of PV 2 and PV 3 are also very prominent, as in S. camelus, and are more rugose and defined than in other ratites. Also as in S. camelus, the pubis and ischium fuse to the ilium around the level of PV 5-6, while they articulate with PV 7-10 without fusion (PV 7 is partly connected to the pubis, and partly to the ischium). The distance between the supratrochanteric process and the antitrochanter is small, as in Struthio, while it is large in Rhea and Casuarius. The shape and relative size of the antitrochanter is as in S. camelus. 'Tuberosity 2' (Fig. 9.2) is large and also characteristic of $S$. camelus. The transverse processes of PV 6-10 are located medial to the acetabulum and visible 
laterally. PV 6 is cranialmost, PV 7-9 are thin and fragile, and PV 10 is considerably thicker and directed more dorsally, a configuation indistinguishable from that of S. camelus.

Prominent dorsoventrally oriented ridges (labelled ridges 1-5 in Fig. 9.2) are present on the preacetabular iliac surfaces. Ridges 2-5 lie just dorsal to the acetabulum. The iliac surfaces between these ridges exhibit rugose muscular attachment areas. A long ridge ('ridge 6') runs cranioventral to caudodorsal along the postacetabular ilium. The cranial ends of the pubis and ischium fuse to each other and to the ilium at the ventral acetabulum, at about the level of PV 6-9.

AUH 1134 differs from extant S. camelus in its larger size (Table 9.1), better-developed tuberosities and muscular ridges on the ilia, and in a dorsal sacral surface that is closed over by a thin sheet of bone. AUH 1134 is noticeably larger than the largest Struthio pelves examined in the AMNH, but the largest specimens of $S$. camelus examined do display a tendency for bony growth along the dorsal sacral surface as well as in generally having more prominent muscular attachment sites. The morphological differences between AUH 1134 and S. camelus may simply be a result of allometric changes related to the fossil specimen's larger size.

Fossil struthionid pelves are rare and only a few have been described. In its morphological differences from S. camelus, the AUH 1134 pelvis appears to match that of Struthio wimani from the 'Pontian' (early Pliocene?) of 'T'ai Chia Kou' in Shanxi Province, China (Lowe, 1931), and perhaps also that of Struthio karatheodoris from the late Miocene of Samos, Greece (Forsyth-Mayor, 1888; Lowe, 1931; Martin, 1903). Struthio transcaucasicus was named based on a pelvis from the late Pliocene of Georgia that was slightly larger than those of S. wimani and S. karatheodoris (BurchakAbramovich and Vekua, 1971). S. oldawayi was described on the basis of several pelvic fragments from the early Pleistocene (Bed I) of Olduvai Gorge in Tanzania and was also reported to differ from extant S. camelus in its larger size (Lowe, 1933).

Measurements of AUH 1134, S. transcaucasicus, S. wimani, and S. karatheodoris (table 1 in Burchak-Abramovich and Vekua, 1971), are mostly larger than those of S. camelus. AUH 1134 is equivalent in size to these other fossils, and the differences among all these fossil specimens do not seem sufficient to warrant specific separation. 
Discussion: From a mess of fossil Struthio names, Boev \& Spassov (2009) recognized four species as valid for the late Miocene of Eurasia. Under their scheme, S. karatheodoris is the name for large struthionid remains from late Miocene of Samos, Pikermi and possibly also Marageh and the Siwaliks. Our comparison suggests that AUH 1134 should also be referred to S. karatheodoris on the basis of its large size.

Younger (Plio-Pleistocene) species also diagnosed on the basis of slightly larger size than extant ostrich - S. wimani, S. transcaucasicus, and S. oldawayi - might represent the same species. It is interesting that AUH 1134 finds its most direct comparison with remains from Eurasia. Though the ostrich is today an Afro-Arabian taxon, the fossil record shows that struthionids were widely distributed across much of the Old World throughout the Neogene, including in Eurasia (e.g., MourerChauviré et al. 1996a,b). Their historical restriction to Africa and Arabia reflects a recent relict distribution, rather than a deep-time biogeographic pattern. The idea that the ostrich represents an African lineage that diverged from the Australasian and South American ratites with the separation of Gondwana has been refuted by both phylogenetic (Mitchell et al., 2014) and developmental (Faux and Field 2017) evidence.

The Baynunah provides a rare example of co-occurrence of both of eggshell and bone remains of Miocene struthionids. It is almost certain that AUH 1134 belongs with one of the two ratite eggshell parataxa from the Baynunah (Bibi et al., 2006, and next section). Of these, Diamantornis laini is believed to be a struthionid, and so may likely belong to the same species as the pelvis AUH 1134. However, one must then ask why no Diamantornis eggshell has been found from Samos, Marageh, the Siwaliks, or in China. Alternative explanations can be proposed (see below).

\section{Ratite eggshells}

[Oogenus] Diamantornis Pickford \& Dauphin, 1993

Diagnosis: Large eggs $(16 \times 13.3 \mathrm{~cm})$, the external surface of which is patterned by large $(2$ to $8 \mathrm{~mm})$ circular (in plan view), funnel-shaped (in section) pore complexes, or 'megapores' (Pickford and 
Dauphin, 1993). Regions of eggshell between the pore complexes are smooth and devoid of small pores; pore complex density ranges from zero to nine pore complexes per $4 \mathrm{~cm}^{2}$; eggshell thickness among the different oospecies of Diamantornis ranges from ca. 2 to $4.5 \mathrm{~mm}$ (Dauphin et al., 1996). Dauphin et al. (1996) describe microstructural characteristics and ratite affinities.

[Oospecies] Diamantornis laini Pickford et al., 1995

Diagnosis: Pore complexes having a diameter of about $5 \mathrm{~mm}$, well separated from each other, with a density of 0-4 pore complexes per $4 \mathrm{~cm}^{2}$. Eggshell thickness ranges from 2.1 to $2.9 \mathrm{~mm}$ (Bibi et al., 2006; Pickford et al., 1995).

Material: 94 collected specimens from sites at Jaw al Dibsa (DBS 2); Hamra (HMR 1, 3, 5); Hadwaniyya (HAD 4, 5, 6); Harmiyyah (HAR 3, 4); Jebel Barakah (JBR 2); Kihal (KIH 3); Ras al Qal'a (RAQ 1, 2); Gerain al Aysh (GAA 3, 4, 8); Ras Dubay'ah (RDB 4); Ruwais (RUW); Shuwaihat (SHU 2, 3, 4, 8); Umm Al Khabir (UAK 1). All specimens were surface finds.

[FIGURES 9.3 and 9.4 NEAR HERE]

Description: No whole eggs have been found in the Baynunah. AUH 1605 from HAD 4 (Fig. 9.3) is the largest reconstructed egg fragment we have for this oospecies. Bibi et al. (2006) provided detailed description of the external morphology of Baynunah D. laini. Mean eggshell thickness was given as $2.8 \mathrm{~mm}$ (range 2.1-3.5 $\mathrm{mm}$ ) and mean pore complex diameter as $4.1 \mathrm{~mm}$ (range 1.4-6.2 $\mathrm{mm}$ ). Eggshell cross-section of Baynunah D. laini reveals continuous and poorly distinguished mammillary, spongy, and external microstructure zones (Fig. 9.4), as previously described for D. laini from Namibia (Dauphin et al., 1996; see also Patnaik et al., 2009).

Eggshells of Holocene Struthio camelus can regularly be found on Baynunah surfaces, and they can be distinguished from $D$. laini (as well as from the next oospecies) by their thinner eggshells 
and tiny pore complexes, as well as typically poor preservation (normally greatly wind-eroded, having been exposed on the surface for decades or centuries).

Discussion: Diamantornis laini was first named from the Miocene of Namibia (Pickford et al., 1995) and later identified at Lothagam in Kenya (Harris and Leakey, 2003; Harrison and Msuya, 2005; Stidham, 2004).

Diamantornis laini is quite common in the Baynunah, and its eggshells can be found at almost all fossils sites, including even highly deflated surfaces such as Umm al Kabir (UAK 1) and Jaw al Dibsa (DBS 2). Of note was the discovery at RAQ 2 in December 2007 of a large surface scatter of hundreds of shell fragments that may have been the remains of a nesting site. Unfortunately, the team returned a year later to find the surface had been gouged by car and heavy vehicle tracks, and the eggshells destroyed or dislocated from their original context (Fig. 9.5).

\section{[FIGURE 9.5 NEAR HERE]}

Oospecies of Diamantornis and Struthio were generally proposed to follow each other in evolutionary succession (Harrison and Msuya, 2005; Pickford et al., 1995 - but see next section below), and Bibi et al. (2006) provided an updated biostratigraphy. The presence of $D$. laini in the Upper Nawata Member at Lothagam, Kenya, dated to 7.5-6.5 Ma (McDougall and Feibel, 2003), has been a main argument for the biostratigraphic age correlation of the Baynunah Formation (Bibi et al. 2013; Bibi et al., this volume-b).

'Aepyornithoid' eggshell ('aepyornithid-type' in Bibi et al., 2006)

Diagnosis (abbreviated from Bibi et al., 2006): Thick eggshell with pore arranged in long and parallel grooves. These can be bent or forked grooves, or short comma-shaped or circular pores (Sauer, 1972). Grooved pores are normally made up of two circular pores connected by a superficial groove. Eggshell thicknesses range from 1.4 to $3.1 \mathrm{~mm}$ (Sauer, 1972; Sauer, 1976; Sauer and Sauer, 1978) 
with individual samples having more conservative thickness ranges. Eggshelss lack the pore complexes characteristic of Diamantornis and Struthio. Aepyornithoid eggshell is extremely similar to that of Aepyornis, the extinct elephant bird of Madagascar, though typically thinner (Sauer, 1972). Aepyornithoid eggshell also bears some resemblance to that of extant Rhea, but differs in its significantly greater thickness.

Material: 30 collected specimens from sites at Bida' al Moutawa'a (BIM 5); Hamra (HMR 1, 3); Hadwaniyya (HAD 3); Kihal (KIH 3); Ras al Qal'a (RAQ 3, 4); Gerain al Aysh (GAA 1,2,3,4); Ruwais (RUW); Shuwaihat (SHU 2); Talfaha (TAL 1). All were surface finds, with the exception of AUH 1602, a fragment collected in situ from a conglomerate layer at HAD 3.

Description: Bibi et al. (2006) provided a detailed description of the Baynunah aepyornithoid eggshell. Only fragments are known. As reported by Bibi et al. (2006), the mean thickness of 25 specimens from the Baynunah is $1.9 \mathrm{~mm}$ (range 1.65-2.3 mm). The Baynunah aepyornithoid eggshell is rarer than that of $D$. laini, and the large majority of specimens were found at a single locality (TAL $1)$.

Discussion: Morphological variation in pore morphology across a single ratite egg has been shown to produce aepyornithoid-type pores in equatorial areas and struthioid (Struthio-like) pores in polar areas (Mourer-Chauviré and Geraads, 2008). However, the presence of two distinct eggshell forms in the Baynunah is clear in the consistency of pore morphology and eggshell thickness within each of the two samples. Aepyornithoid eggshell has also been reported from Neogene sites in Kenya (Harris and Leakey, 2003), Egypt (Smith, 2013), Morocco (Sauer and Sauer, 1978), Namibia (Mourer-Chauviré et al., 1996a,b), Turkey (Sauer, 1976), the Canary Islands (Sauer and Rothe, 1972; but see GarciaTalavera, 1990; Mayr, 2011), and mainland Spain (Mein and Dauphin, 1995), as well as from India, Pakistan and Mongolia (Sauer, 1972; Grellet-Tinner, 2006; Patnaik et al., 2009). In part, these occurrences - especially the more fragmentary ones - should be regarded with caution, since detailed analyses, including of microstructure, are generally lacking, and ratite-looking structure occurs in 
eggshells of several non-ratite, neognathous taxa (Mayr, 2011). Since the aepyornithoid pore pattern is found in both Aepyornis and Rhea, it may well be a conserved (plesiomorphic) morphology for ratites as a whole (Bibi et al., 2006). For example, an Eocene North American locality yielded eggshells described as similar to aepyornithoid, even though the associated bird is unlikely to be a ratite (Hirsch et al., 1997). The different fossil occurrences of aepyornithoid eggshell certainly represent several, perhaps very different, species of ratite.

There are several possible associations of aepyornithoid eggshells and ratite skeletal remains. Occurrences of aepyornithoid eggshells associated with small Struthio (S. coppensi) skeletal remains in the early Miocene of Namibia suggest that these eggs were made by a struthionid lineage (MourerChauviré et al., 1996a,b). Aepyornithoid eggshells are also associated with bones of a small Struthio at the middle Miocene site of Fort Ternan in Kenya (Rich 1974, Leonard et al. 2006). At least some occurrences of aepyornithoid eggshell may therefore have been made by a struthionid ratite.

At the same time, a second lineage of struthionid birds, probably of larger size, is hypothesized to have produced the Namornis-Diamantornis lineage of eggshells, which is well documented in the Miocene of Namibia, and which is proposed to have eventually given rise to extant Struthio (Pickford et al., 1995). This leads to a scenario with two struthionid lineages (both containing species classified as Struthio) evolving in parallel, and both spreading from Africa to Eurasia, though possibly at different times (middle Miocene for the smaller lineage associated with aepyornithoid eggshell, and late Miocene for the larger lineage associated with Namornis-Diamantornis-Struthio-type eggshells; Mourer-Chauviré et al., 1996a,b). The latest records of aepyornithoid eggshell are generally in the Pliocene, with even younger mentions in the Siwaliks of the Potwar Plateau, Pakistan, until 1.3 Ma (Stern et al., 1994; Louchart, in press), suggesting that the aepyornithoid lineage became extinct in the early Pleistocene. It is even possible that part of the aepyornithoid ootype evolved into struthioid eggshell into the Pleistocene and later (Mourer-Chauviré and Geraads, 2008). In the second lineage, eggshell would have evolved into the Struthio-type around the Pliocene (Harrison and Msuya, 2005; Bibi et al., 2006), only dispersing across Eurasia after this time. This would explain the absence of Diamantornis eggshell in Eurasia with the exception of the Baynunah. Concerning the Diamantornis Struthio transition, it is interesting that the present-day Somali ostrich, Struthio molybdophanes, lays 
eggs with megapore complexes similar to the youngest Diamantornis oospecies, albeit slightly smaller and denser (Mourer-Chauviré and Geraads, 2008). Struthio molybdophanes-like eggshell, found in the Pliocene of Morocco (associated with the large Struthio cf. asiaticus; Mourer-Chauviré and Geraads, 2008) and in the late Pleistocene of India (Blinkhorn et al., 2015), appear to provide further evidence of a direct relationship between Diamantornis and extant ostriches.

Neognathae Pycraft, 1900

Suliformes Sharpe, 1891

Phalacrocoracidae (Bonaparte, 1853)

Phalacrocorax Brisson, 1760

Phalacrocorax sp.

Material: proximal left carpometacarpus (AUH 1106, RAQ 2-1); distal right tarsometatarsus (AUH 1326, SHU 2-2); and a tentatively referred proximal right humerus fragment (AUH 1104, RAQ 2-1). Figures 9.6 and 9.7.

[FIGURES 9.6 AND 9.7 NEAR HERE]

Description: The proximal left carpometacarpus (AUH 1106) matches the corresponding bone of Phalacrocorax (cormorant) and differs from that of Anhinga in the following characters: fovea carpalis cranialis shallower, processus extensorius less protruding cranially, and the dorsal border of the trochlea carpalis more rounded (not pointed). The distal right tarsometatarsus (AUH 1326) is also consistent with Phalacrocorax and differs from Anhinga in the following characters: subdistal part of the shaft with a more square section and less flattened dorso-ventrally; foramen vasculare distale proportionately larger. The proximal right humerus (AUH 1104) exhibits, as in cormorants, a caput humeri that is narrower proximo-distally, more elongated dorso-ventrally, and less protruding proximally, than in Anhinga. 
Specific assignment of these cormorant fossils is not currently possible, but dimensions help to possibly identify the Phalacrocorax subgenus. The proximal carpometacarpus, with a proximal width of $12.3 \mathrm{~mm}$, is slightly larger than in three modern P. aristotelis specimens (UCBL) $(11.0 \mathrm{~mm}$; $11.1 \mathrm{~mm} ; 11.2 \mathrm{~mm}$ ); the distal tarsometatarsus, broken, eroded and incomplete, suggests dimensions slightly smaller than those same $P$. aristotelis specimens; the proximal humerus, with a proximal width of $18.0 \mathrm{~mm}$, is slightly smaller than the following P. aristotelis specimens (respectively 20.7 $\mathrm{mm} ; 20.6 \mathrm{~mm} ; 20.6 \mathrm{~mm})$. Hence, the inter-segment proportions between these three elements, as well as their dimensions, suggest close similarity to the subgenus Phalacrocorax, the most similar species being apparently the extant $P$. (P.) fuscicollis (see dimensions and ratios in Brodkorb and MourerChauviré, 1984), especially if the Baynunah carpometacarpus and tarsometatarsus dimensions reflect rather large individuals. We could not compare the Baynunah fossils to P. nigrogularis (extant Socotra cormorant), though it seems an unlikely match since it is exclusively a coastal species and is generally placed in the subgenus Leucocarbo, which typically exhibits different skeletal element proportions (Brodkorb and Mourer-Chauviré, 1984). We assign these fossils to a Phalacrocorax species the size of $P$. (P.) fuscicollis (the Indian cormorant). This species today inhabits freshwater and marine habitats from India and Pakistan to Indochina. The late Miocene fossils might belong to an ancestral lineage, the distribution of which was larger and encompassed suitable aquatic settings with fish in the Arabian Peninsula.

Anhingidae Ridgway, 1887

Anhinga Brisson, 1760

Anhinga sp., cf. A. hadarensis Brodkorb \& Mourer-Chauviré, 1982

Material: proximal right scapula (AUH 1113, RAQ 2-1); proximal right scapula (AUH 1287, HMR 2-2); left coracoid fragment (AUH 1592, HAD 3); left coracoid fragment (AUH 1319, SHU 2-2); left humerus (AUH 1489, SHU 2-6); proximal fragment of shaft of right humerus (AUH 1722, HDS 1); distal right coracoid (AUH 1796, GAA 2); distal right humerus (unnumbered 'ADIAS 1421', RUW C). See Figs. 9.6 and 9.7. 
Description: The complete left humerus (AUH 1489) resembles Anhinga spp. (darters) and differs from Phalacrocorax spp., in that the proximal end of the crista bicipitalis meets the shaft abruptly (graduated in Phalacrocorax); the distal end of the humerus is also less splayed, narrower and generally more gracile in appearance, as in Anhinga; and the tuberculum supracondylare ventrale is elongated in the ventro-distal direction (dorso-distal in Phalacrocorax). The proximal end is also proportionately narrower, and the caput humeri more protruding proximally, as in Anhinga. The latter feature is especially similar to the condition in A. rufa and A. melanogaster and less like that in $A$. anhinga. The right fragmentary humerus shaft (AUH 1722) includes the beginning of the crista pectoralis and crista bicipitalis where the shaft broadens and flattens towards the proximal end. The right scapulae (AUH 1113 and AUH 1287) match Anhinga in that the facies articularis humeralis protrudes more laterally and its caudal border meets the collum scapulae more abruptly than in Phalacrocorax. The proximal left coracoid fragments (AUH 1319 and AUH 1592) match Anhinga in the processus acrocoracoideus being relatively wider and less pointed, giving it a shape like an isosceles triangle (in lateral view); the facies articularis clavicularis is elongated in a transverse (almost dorso-ventral) direction (proximo-sternal direction in Phalacrocorax). The distal right coracoid (AUH 1796) was described by Stewart and Beech (2006, their figure 6) though at the time it was an unnumbered specimen. The unnumbered distal right humerus was also described by Stewart and Beech (2006, their figure 5) under the field number ADIAS (Abu Dhabi Islands Archaeological Survey) 1421.

Discussion: The Anhinga elements from the late Miocene Baynunah Formation need to be considered in light of modern members of the genus as well as other Neogene fossils from the region. The genus Anhinga today comprises four species distributed globally across the tropics (Del Hoyo et al. 2017). These are A. anhinga in the New World, A. rufa in sub-Saharan Africa and Madagascar, $A$. melanogaster in southeast Asia, and A. novaehollandiae in Australasia. Numerous Neogene localities around the world have also yielded a number of fossil species of Anhinga, including several in the New World, often of great size (see Louchart et al. 2008). In the Old World, and including in the late 
Neogene of Africa, fossil species include A. pannonica (Louchart et al. 2008) and A. hadarensis (Brodkorb and Mourer-Chauviré 1982). Among extant species, the Baynunah darter is generally comparable in size to New World $A$. anhinga, but differs in at least one discrete character of the humerus (protruding caput humeri). The Baynunah darter is therefore more similar to the Old World species, but is generally smaller, or at the lower end of the variation intervals of $A$. melanogaster and A. rufa (Table 2). In addition, some measurements differ more than others among the Baynunah elements (including those previously reported in Stewart and Beech 2006) and those of extant species. In the Baynunah species, compared with extant darters, the humerus is relatively shorter and more robust (greater shaft width), and the oblique length of the processus acrocoracoideus of the coracoid is lower (relative to its oblique width) (Table 9.2). In this regard, the proximal coracoid is similar in proportions to that of $A$. hadarensis from the Plio-Pleistocene of East Africa; in addition, the relatively short and robust humerus is consistent with the general observation that in A. hadarensis several long bones (and scapular region bones) are relatively short and robust (with greater relative depths, Table 9.2; Brodkorb and Mourer-Chauviré 1982). A. hadarensis also exhibits measurements that are generally smaller, or at the lower end of the variation intervals of $A$. melanogaster (Brodkorb and Mourer-Chauviré 1982). Unfortunately, only the proximal coracoid can be compared directly between A. hadarensis and the Baynunah darter. Therefore, we only tentatively assign the Baynunah fossils to A. hadarensis, pending the discovery of more material. Among fossil taxa, A. pannonica is substantially larger than A. melanogaster (Louchart et al. 2008), and no other fossil species (including outside the Old World) approaches the Baynunah darter in size or proportions (see refs. in Louchart et al. 2004, 2008).

Small fossil darters are also known from the late Miocene of Chad and Ethiopia, ca. 7 to $5 \mathrm{Ma}$ (Louchart et al. 2008). These were assigned to Anhinga cf. A. melanogaster, but could belong to $A$. hadarensis. Fossils from the Pliocene of Chad (Louchart et al. 2004) are even more confidently assignable to A. hadarensis, as they exhibit a cranially elongated and protruding processus extensorius of the carpometacarpus, and a relatively deep (thick) but narrow os metacarpale majus. Another occurrence of a relatively small darter, from the early Pleistocene of Konso (Ethiopia), in contrast, seems to be more similar to A. rufa or A. melanogaster, and to differ from A. hadarensis (Louchart 
2014). The mention of darter bones apparently similar to A. rufa from the late Miocene (Harris and Leakey 2003) and early Pliocene (Field 2017) of Kenya should be re-examined. It might be that two lineages of small darters coexisted in northeastern Africa during the late Miocene to Pleistocene, one related to $A$. hadarensis, and the other more similar to $A$. rufa. However, it is still not certain whether A. hadarensis represents an extinct side branch, or whether it might be ancestral to the lineage leading to modern A. rufa.

Anhinga rufa and A. melanogaster are today separated by an extensive arid region spanning from Sudan to Pakistan, and extending over the Arabian Peninsula. The sole exception is a relict, endangered population (A. r. chantrei) that survives at the Iraq-Iran border (Del Hoyo et al. 2017). The Baynunah Anhinga provides an extension of the darter fossil record into the Arabian Peninsula, and may represent a geographic link between the extant African and Asian species.

Pelecaniformes Sharpe, 1891

Ardeidae Leach, 1820

Nycticoracini Bonaparte, 1854

Nycticoracini gen. et sp. indet.

Material: Left coracoid (AUH 1496, HMR 1-3), Fig. 9.6C. Possibly also distal right coracoid fragment (AUH 126, SHU 2) and partial left scapula (unnumbered, SHU 1).

Description: The left coracoid (AUH 1496) is in two fragments, the shoulder extremity and sternal extremity. These were found together, have similar preservation and breakage patterns, and similar grey sediment infilling their shafts, although they do not conjoin. The shoulder extremity clearly belongs to an ardeid (heron) with a prominent processus procoracoideus (broken). The shaft of the proximal extremity has been repaired. There is a fossa below the processus acrocoracoideus which is located in the sulcus $\mathrm{m}$. supracoracoidei. This fossa is variably present among modern ardeid individuals within species. AUH 126 is a coracoid that was the basis for 'Egretta aff. alba' in the Baynunah faunal list of Whybrow \& Clements (1999), but was later described by Stewart and Beech 
(2006: their fig. 7) as an indeterminate ardeid. In AUH 126, the area below the processus acrocoracoideus had sediment adhering to it which may have obscured a similar fossa to that in AUH 1496. The sternal extremity is also broken and does not bear any informative characters.

AUH 1496 corresponds in all features to the Nycticoracini, such as the extant night herons Nycticorax nycticorax and Nyctanassa violacea. AUH 1496 differs from species of Ardea (A. purpurea, A. cinerea), Botaurus (B. stellaris), Bubulcus (B. ibis) and Egretta (E. garzetta) in having a processus acrocoracoideus that is more acute and more projecting proximally. Also, the whole proximal (humeral) part of the bone is relatively narrower, and its ventral border in medial view is less markedly sigmoidal than seen in Ardea (and Botaurus). The facies articularis clavicularis in AUH 1496 is wider than in Bubulcus. The line delimiting the proximal end of the facies articularis sternalis is much weaker than in Botaurus and A. cinerea. In the fossil, this line is also straighter, and more evenly protruding in relief. The facies art. stern. is relatively slightly wider (sterno-humerally) than in Bubulcus (although this feature varies intraspecifically). The sternal limit of the bone (and the facies art. sternalis) in dorsal view forms a greater-radius concavity than in Botaurus. AUH 1496 shows even greater differences to Ardeola ralloides. Although the proc. acrocor. is acute and comparably projecting in A. ralloides, AUH 1496 and the Nycticoracini, the ventral part of the facies art. clav. forms a much less projecting extension (ventrally), the ventral border of the proximal shaft is markedly less sigmoidal, and the humeral limit of the facies art. stern. is a much longer line, less in protruding relief, than in A. ralloides. The small fossa visible just below the facies articularis clavicularis in AUH 1496 in medial view might be diagnostic and differentiate it from the extant species (although Bubulcus ibis shows a comparable, shallow fossa).

We confidently assign AUH 1496 to Nycticoracini, but cannot further determine its identity. Among the members of this tribe, Nycticorax would make a better candidate than Nyctanassa, as Nycticorax is cosmopolitan, with the species $N$. nycticorax being nearly cosmopolitan (only absent from Australasia), while Nyctanassa is restricted to the New World. AUH 1496 has dimensions that fit with those of a large individual of Nycticorax nycticorax (estimate of medial length, ca. 51-52 mm; maximum width of processus acrocoracoideus, ca $9.0 \mathrm{~mm}$; least width of corpus, ca. $4.0 \mathrm{~mm}$ ). 
The partial left scapula (unnumbered) and the partial coracoid (AUH 126) were described as unnumbered specimens by Steward and Beech (2006, their figure 8 ) and attributed to an indeterminate ardeid. With the clear identification of AUH 1496 as a representative of the Nycticoracini, it is possible that these two specimens also belong to the same taxon, but a lack of diagnostic morphology makes this uncertain.

Discussion: Although Mayr (2014) considered that the coracoid from the middle Miocene of Maboko Island, Kenya, assigned by Dyke and Walker (2008) to Nycticorax cf. nycticorax exhibited a less developed facies art. clav. than in the extant genus, we find that this feature is variable intraspecifically, and that some extant Nycticorax spp. specimens show a similarly weakly developed (narrow) facies art. clav. Compared with extant Nycticoracini, the Maboko Island coracoid shows a better-marked S-shaped ventral border of the humeral part of the shaft below the facies art. clav. in medial view. Despite this slight difference, the Maboko Island coracoid is similar to that in the Nycticoracini, and differs from other tribes. Thus, it can still be assigned to the Nycticoracini.

Nycticorax-like heron fossils have been reported from sites as early as the Oligocene of the Fayum, Egypt (Rasmussen et al. 1987). Similar to the darter and the cormorant described above, a nycticoracine heron indicates the presence of water bodies with fish and other animals.

\section{Paleoecological implications}

The small collection of avian remains from the late Miocene of Abu Dhabi has much in common with those from similarly aged sites in Africa. Table 9.3 lists the occurrences of bird families from African late Miocene fossil sites, showing that all the avian taxa in the Baynunah are also present in most contemporaneous African sites. Most of these sites have (in decreasing commonness of occurrence) darters, cormorants, and herons. Skeletal remains of ostriches are quite rare, and in the late Miocene they occur only in northern Africa, although ratite eggshell fragments are much more widespread.

Ecologically, the Baynunah fossil birds present an aquatic to terrestrial ratio of 3 species to 1 . A compilation of 19 late Miocene African sites gives ratios ranging from 2 to 1 (less aquatic) and 5 to 
0 (highly aquatic) (a single site with only ostrich being obviously a bias of collection in the field). This is not surprising for fossil avifaunas from fluvial and lacustrine environments, and the same is true for the well-documented European Middle Pleistocene (Tyrberg 1998; Stewart 2010).

At 18 African late Miocene sites, (Table 9.3), the ratios of piscivorous to herbivorous taxa among aquatic birds are as follows: 0:1 (3 sites), 1:1 (1), 1:0 (6), 2:0 (3), 3:1 (2), 3:0 (1), 4:1 (1), 5:0 (1). The Baynunah fossil birds, with a ratio of 3:0, fit the same scheme as late Miocene Africa in general. In contrast, in the European late Miocene, surface-feeding anseriforms and other herbivorous aquatic birds dominate, both in taxonomic diversity and specimen abundance, over piscivorous aquatic birds (Mlikovsky 2002). It is unclear whether this is due to some sort of taphonomic bias, or to an as yet unknown ecological factor. This trend also needs to be confirmed by more data.

Recent avian phylogenies (Ericson et al. 2006, Jarvis et al. 2014, Prum et al. 2015) show a piscivorous-herbivorous dichotomy in aquatic birds to have a strong phylogenetic and geographic signal. Avian species diversity in freshwater bodies in northern latitudes is dominated, both today and in the Pleistocene, by largely herbivorous Anseriformes. In contrast, in Africa as well as in the Baynunah freshwater birds are mainly piscivorous non-anseriform birds (Cramp 1998 vs. Brown et al. 1982 and Urban et al. 1986). A hypothesis to explain this may be that these areas are where the respective fresh-water aquatic birds radiated which in turn may have an ecological control, given that the piscivorous and anseriform birds differ significantly in their trophic positions. This intriguing biogeographic pattern in modern and fossil communities remains to be explained.

\section{Conclusions}

The Baynunah Formation birds include the rare co-occurrence of ratite bone remains along with two different types of ratite eggshells. Otherwise, taxonomic diversity is dominated by aquatic birds, with at least a single species each of a darter, a cormorant, and a heron. Future research in the Arabian Peninsula will yield important data that will help further determine the role of this region in faunal exchanges between Asia, Africa and Europe, especially in the late Miocene. 


\section{Acknowledgments}

Research in Abu Dhabi has been supported by the Historic Environment Department of the Department of Culture and Tourism (formerly Abu Dhabi Tourism and Culture Authority). A.L. would like to thank Christine Lefèvre (MNHN, Paris) for the loan of comparative modern specimens. The photographs in Figs 9.6 and 9.7 were taken by Alex Otto of Bournemouth University. F.B. acknowledges support of an International Research Fellowship Award (National Science Foundation Grant 0852975).

\section{References}

Ballmann, P. 1987. A fossil bird fauna from the Pliocene Sahabi formation of Libya; pp. 113-118. In Boaz N. T., El-Arnauti, A., Gaziry, A. W., Heinzelin, J. de \& Boaz, D. D. (eds.) Neogene paleontology and geology of Sahabi. Alan R. Liss, Inc., New York.

Baumel, J. J. \& Witmer, L. M. (1993). Osteologia. In J. J. Baumel, A. S. King, J. E. Breazile, H. E. Evans \& J. C. Vanden Berge (Eds) Handbook of Avian Anatomy: Nomina Anatomica Avium. Publications of the Nuttall Ornithological Club, 23, 45-132.

Becker, J.J. 1986. Reidentification of "Phalacrocorax" subvolans_Brodkorb as the earliest record of Anhingidae. The Auk, 103: 804-808.

Bibi F, Shabel A.B., Kraatz B.P., Stidham T.A. 2006. New fossil ratite (Aves: Palaeognathae) eggshell discoveries from the late Miocene Baynunah Formation of the United Arab Emirates, Arabian Peninsula. Palaeontol Electronic 9(1), 2A: 13p.

Bibi F., Hill A., Beech M. et al. 2013. Late Miocene fossils from the Baynunah Formation, United Arab Emirates: Summary of a decade of new work. In: Wang X., Flynn L. J. Fortelius M. (ed) Fossil Mammals of Asia: Neogene Biostratigraphy and Chronology, Columbia Univ. Press, New York, p 583-594. 
Bibi, F., Beech, M., Hill., A, \& Kraatz, B. (this volume-a). Fossil Localities of the Baynunah Formation. In F. Bibi, B. Kraatz, M. Beech, \& A. Hill (eds.) Sands of Time: Late Miocene Fossils from the Baynunah Formation, U.A.E. (pp. xxx). Cham: Springer.

Bibi, F., Kaya, F., Varela, S. (this volume-b). Paleoecology and Paleobiogeography of the Baynunah Fauna. In F. Bibi, B. Kraatz, M. Beech, \& A. Hill (eds.) Sands of Time: Late Miocene Fossils from the Baynunah Formation, U.A.E. (pp. xxx). Cham: Springer.

Blinkhorn, J., Achyhutan, H., and M.D. Petraglia. 2015. Ostrich expansion into India during the late Pleistocene: Implications for continental dispersal corridors. Palaeogeography, Palaeoclimatology, Palaeoecology, 417:80-90.

Boev, Z., and N. Spassov. 2009. First record of ostriches (Aves, Struthioniformes, Struthionidae) from the late Miocene of Bulgaria with taxonomic and zoogeographic discussion. Geodiversitas, 31(3):493-507.

Brodkorb P. and Mourer-Chauviré C. 1982. Fossil anhingas (Aves: Anhingidae) from early man sites of Hadar and Omo (Ethiopia) and Olduvai Gorge (Tanzania). Geobios, 15: 505-515.

Brodkorb P. and Mourer-Chauviré C. 1984. A new species of cormorant (Aves: Phalacrocoracidae) from the Pleistocene of Olduvai Gorge, Tanzania. Geobios, 17: 331-337.

Brown L.H, Urban E.K., and Newman, K. 1982. Birds of Africa Volume 1: Ostriches to Falcons. Academic Press, London.

Burchak-Abramovich, N. I., and A. Vekua. 1971. The fossil ostrich from the Akchagil Layers of Georgia. Acta Zoologica Cracoviensia, 16:1-26.

Cramp, S. 1998. The Complete Birds of the Western Palearctic on CD-ROM. Oxford Univ. Press, Oxford.

Dauphin, Y., M. Pickford, and B. Senut. 1996. Microstructures des coquilles d'oeufs d'oiseaux fossiles de Namibie. Revue de Paleobiologie, 15(1):225-241.

del Hoyo, J., Elliott, A., Sargatal, J., Christie, D.A. \& de Juana, E. (eds.) (2017). Handbook of the Birds of the World Alive. Lynx Edicions, Barcelona. (retrieved from http://www.hbw.com/ on 15 September 2017). 
Dyke G.J. and Walker C.A. 2008. New records of fossil « waterbirds » from the Miocene of Kenya. American Museum Novitates, 3610: 1-12.

Ericson P.G.P., Anderson C.L., Britton T., Elzanowski A., Johansson U.S., Källersjö M., Ohlson J.I., Parsons T.J., Zusson D. and Mayr G. 2006. Diversification of Neoaves: integration of molecular sequence data and fossils. Biology Letters, 2: 543-547.

Faux C. and Field D.J. 2017. Distinct developmental pathways underlie independent losses of flight in ratites. Biology Letters 13: 20170234. http://dx.doi.org/10.1098/rsbl.2017.0234

Field D. 2017 in press. Preliminary paleoecological insights from the Pliocene avifauna of Kanapoi, Kenya: implications for the ecology of Australopithecus anamensis. J. Human Evol.

Forsyth-Mayor, C. J. 1888. Sur un gisement d'ossements fossiles dans l'isle de Samos, contemporains de l’ăge de Pikermi. Comptes rendus de l'Académie des sciences Paris, 107:1178-1181.

Garcia-Talavera, F. 1990. Aves gigantes en el Mioceno de Famara (Lanzarote). Revista de la Academia Canaria de la Ciencia, 2:71-79.

Grellet-Tinner, G. 2006. Phylogenetic interpretations of eggs and eggshells: implications for phylogeny of Palaeognathae. Alcheringa, 30:141-182.

Harris, J. M., and M. G. Leakey. 2003. Lothagam birds, p. 161-166. In M. G. Leakey and J. M. Harris (eds.), Lothagam: the Dawn of Humanity in Eastern Africa. Columbia University Press, New York.

Harris J.M., Leakey M.G. and Cerling T.E. 2003. Early Pliocene tetrapod remains from Kanapoi, Lake Turkana Basin, Kenya. Natural History Museum of Los Angeles County Contributions in Science, 498: 39-113.

Harrison, T., and C. P. Msuya. 2005. Fossil struthionid eggshells from Laetoli, Tanzania: taxonomic and biostratigraphic significance. Journal of African Earth Sciences, 41:303-315.

Hirsch, K.F., Kihm, A.J., and D.K. Zelenitsky. 1997. New eggshell of ratite morphotype with predation marks from the Eocene of Colorado. Journal of Vertebrate Paleontology, 17:360-369.

Holt, B. G., Lessard, J.-P., Borregaard, M. K., Fritz, S. A., Aráujo, M. B., Dimitrov, D., Fabre, P.-H., Graham, C. H., Graves, G. R., Jønsson, K. A., Nogués-Bravo, D., Wang, Z., Whittaker, R. J., 
Fjeldsä, J. \& Rahbek, C. 2013. An update of Wallace's zoogeographic regions of the world. Science 339: 74-77.

Jarvis E.D. et al. 2014. Whole-genome analyses resolve early branches in the tree of life of modern birds. Science, 346: 1320-1331.

Leonard, L.M., Dyke, G.J., and Walker, C.A. 2006. New specimens of a fossil ostrich from the Miocene of Kenya. Journal of African Earth Sciences, 45:391-394.

Louchart, A. 2014. "Fossil birds of the Konso Formation". In Gen Suwa, Yonas Beyene, Berhane Asfaw, Eds., The Konso-Gardula Research Project: Paleontological Collections, Volume 1. Background, Fossil Cercopithecidae, Suidae, and Aves. Tokyo: University Museum, University of Tokyo Bulletin series, 47, pp. 25-39.

Louchart, A. in press. "Birds". In Catherine Badgley, David Pilbeam, Michèle Morgan, Eds., At the Foot of the Himalayas: Paleontology and Ecosystem Dynamics of the Siwalik Record of Pakistan. Baltimore: Johns Hopkins University Press.

Louchart, A., Mourer-Chauviré, C., MacKaye, H.T., Likius, A., Vignaud, P. \& Brunet, M. 2004. Les oiseaux du Pliocène inférieur du Djourab, Tchad, Afrique Centrale. Bulletin de la Société géologique de France 175 (4): 413-421.

Louchart, A., Haile-Selassie, Y., Vignaud, P., Likius, A. \& Brunet, M. 2008. Fossil birds from the Late Miocene of Chad and Ethiopia and zoogeographical implications. Oryctos 7: 147-167.

Lowe, P. R. 1931. Struthious remains from China and Mongolia; with description of Struthio wimani, Struthio anderssoni and Struthio mongolicusspp. nov. Palaeontologia Sinica, Ser C, 6(4):1-40.

Lowe, P. R. 1933. On some struthious remains. Ibis, 13:652-658.

Martin, R. 1903. Note on some remains of Struthio karatheodorisMajor on the island of Samos.

Proceedings of the Zoological Society of London, 1(1903):203-210.

Mayr G. 2011. Cenozoic mystery birds - on the phylogenetic affinities of bony-toothed birds (Pelagornithidae). Zoologica Scripta, 40: 448-467.

Mayr G. 2014. On the middle Miocene avifauna of Maboko Island, Kenya. Geobios, 47: 133-146.

McDougall, I and C. S. Feibel. 2003. Numerical age control for the Miocene-Pliocene succession at Lothagam, a hominoid-bearing sequence in the northern Kenya Rift, p. 43-64. In M. G. Leakey 
and J. M. Harris (eds.), Lothagam: the Dawn of Humanity in Eastern Africa. Columbia University Press, New York.

Mein, P., and Y. Dauphin. 1995. Aepyornithid eggshells in the basal Pliocene of Teruel Basin (Spain). N. Jb. Geol. Paläont. Mh., 1995, H. 3: 182-191.

Mlikovsky, J. 2002. Cenozoic Birds of the World. Part 1: Europe. Ninox Press, Prague.

Mitchell, K. J., B. Llama, J. Soubrier, N. J. Rawlence, T. H. Worthy, J. Wood, M. S. Y. Lee, and A. Cooper. 2014. Ancient DNA reveals elephant birds and kiwi are sister taxa and clarifies ratite bird evolution. Science, 344(6186):898-900.

Mourer-Chauviré, C., Senut, B., Pickford, M., and Mein, P. 1996a. The oldest representative of the genus Struthio (Aves: Struthionidae), Struthio coppensi n. sp., from the Lower Miocene of Namibia. Comptes Rendus de l'Académie des Sciences, Série II, Sciences de la Terre et des Planètes, 322(4):325-332.

Mourer-Chauviré, C., Senut, B., Pickford, M., Mein, P., and Dauphin, Y. 1996b. Ostrich legs, eggs and phylogenies. South African Journal of Science, 92(10):492-495.

Mourer-Chauviré, C., and D. Geraads. 2008. The Struthionidae and Pelagornithidae (Aves: Struthioniformes, Odontopterygiformes) from the late Pliocene of Ahl al Oughlam, Morocco. Oryctos, 7:169-194.

Patnaik, R., Sahni, A., Cameron, D., Pillans, B., Chatrath, P., Simons, E., Williams, M., and F. Bibi. 2009. Ostrich-like eggshells from a 10.1 million-yr-old Miocene ape locality, Haritalyangar, Himachal Pradesh, India. Current Science, 96:1485-1495.

Pickford, M., and Y. Dauphin. 1993. Diamantornis wardi nov. gen., nov. sp. giant extinct bird from Roilepel, Lower Miocene, Namibia. Comptes Rendus de l'Académie des Sciences, 316:16431650.

Pickford, M., B. Senut, and Y. Dauphin. 1995. Biostratigraphy of the Tsondab Sandstone (Namibia) based on gigantic avian eggshells. Geobios, 28(1):85-98.

Pickford M., Senut B., Hipondoka M., Person A., Segalen L., Plet C., Jousse H., Mein P., Guérin C., Morales J. and Mourer-Chauviré C. 2009. Mio-Plio-Pleistocene geology and palaeobiology of Etosha Pan, Namibia. Communs geol. Surv. Namibia, 14: 95-139. 
Prum R.O., Berv J.S., Dornburg A., Field D.J., Townsend J.P., Moriarty Lemmon E. and Lemmon A.R. 2015. A comprehensive phylogeny of birds (Aves) using targeted next-generation DNA sequencing. Nature, 526: 569-573.

Rasmussen D.T, Olson S.L. and Simons E.L. 1987. Fossil birds from the Oligocene Jebel Qatrani Formation, Fayum Province, Egypt. Smithsonian Contributions to Paleobiology, 62: 1-20.

Rich, P. V. 1972. A fossil avifauna from the Upper Miocene Beglia formation of Tunisia. Notes $d u$ Service géologique, Travaux Géol. Tunis., 35: 29-66.

Rich, P. V. 1974. Significance of the Tertiary avifaunas from Africa (with emphasis on a mid to late Miocene avifauna from Southern Tunisia). Annals of the Geological Survey of Egypt, 4: 167210.

Sauer, E. G. F. 1972. Ratite eggshells and phylogenetic questions. Bonner Zoologische Beitrage, 23(1):3-48.

Sauer, E. G. F. 1976. Aepyornithoide Eierschalen aus dem Miozaen und Pliozaen von Anatolien, Tuerkei. Aepyornithoid eggshell fragments from the Miocene and Pliocene of Anatolia, Turkey. Palaeontographica. Abteilung A: Palaeozoologie-Stratigraphie, 153(1-3):62-115.

Sauer, E. G. F., and P. Rothe. 1972. Ratite eggshells from Lanzarote, Canary Islands. Science, 176(4030):43-45.

Sauer, E. G. F., and E. M. Sauer. 1978. Ratite eggshell fragments from Mio-Pliocene-continental sediments in the district of Ourzazate, Morocco. Palaeontographica. Abteilung A: Palaeozoologie-Stratigraphie, 161(1-3):1-54.

Smith, N. A. 2013. Avian fossils from the early Miocene Moghra Formation of Egypt. Ostrich, 84(3):181-189.

Stern, L. A., Johnson, G. D., and C. P. Chamberlain. 1994. Carbone isotope signature of environmental change found in fossil ratite eggshells from a south Asian Neogene sequence. Geology, 22: $419-422$.

Stewart J.R. 2010. The bird remains from the West Runton Freshwater Bed Norfolk, England. Quaternary International, 228: 72-90. 
Stewart, J. R. \& Beech, M. 2006. The Miocene birds of Abu Dhabi (United Arab Emirates) with a discussion of the age of modern species and genera. Historical Biology, 18: 103-113.

Tyrberg T. 1998. Pleistocene birds of the Palearctic: a catalogue. The Nuttall Ornithological Club, Cambridge, Massachussets, 720 pp.

Urban E.K., Fry H.C. and Keith, S. 1986. Birds of Africa Volume II: Gamebirds to Pigeons. London: Academic Press. 552 pp.

Whybrow, P. J. and D. Clements. 1999. Arabian Tertiary fauna, flora, and localities; pp. 460-473 in P. J. Whybrow and A. Hill (eds.), Fossil Vertebrates of Arabia. Yale University Press, New Haven. 


\section{Tables}

Table 9.1. Measurements (mm) of AUH 1134 pelvis and four large S. camelus pelves in the AMNH (AMNH SKEL 1821, 1294, 996, 965).

\section{Measurement}

Straight distance from cranio-ventral iliac projection to caudal end of ilium

Straight distance from cranio-ventral ilium projection to caudalmost ischium

Straight distance from cranio-ventral ilium projection to caudal end of acetabulum

Straight distance from cranio-dorsal iliac projection to the midpoint between the supra- and anti-trochanters

Supratrochanter to caudal end of ilium

Straight distance from cranio-dorsal iliac projection to caudal end of ilium

Acetabulum craniocaudal diameter

Acetabulum dorsoventral diameter

PV 1 centrum cranial articular surface, maximum width

PV 1 centrum cranial articular surface, maximum dorsoventral depth

PV 1 length of spine from base to top of iliac crest

Maximum width across antitrochanters

$\begin{array}{rr}\text { AUH 1134 } & \text { S. camelus } \\ 638+ & 515-565 \\ 687 & 515-545 \\ 263 & 185-205 \\ 304 & 215-245 \\ & \\ 349+ & 310-345 \\ 647+ & 520-585 \\ 75 & 51-58 \\ 66 & 52-55 \\ 51 & 46.4-53.5 \\ 28 & 16.4-21.8 \\ & 88-106 \\ 129 & 172-198\end{array}$

Table 9.2. Measurements of the Baynunah fossils of Anhinga, with homologous measurements of modern species, as well as of the fossil Anhinga hadarensis, for comparison. All in millimeters. x, not measurable. From present work and published data (indicated for taxa concerned). m1: scapula proximal diagonal width. m2: scapula proximal depth. m3: coracoid proximal diagonal width of processus acrocoracoideus; and underlined, a parallel measurement just below the proc.

acrocoracoideus. m4: coracoid oblique length of furcular facet of proc. acrocor. (as measurement ' 3 ' of Brodkorb and Mourer-Chauviré 1982). m5: coracoid oblique "width" of the proc. acrocor. (anterior 
face, as measurement '2' of Brodkorb and Mourer-Chauviré 1982). m6: humerus length. m7: humerus proximal width. m8: humerus distal width (minimal, i.e. measured slightly oblique to the plane of the bone). m9: humerus distal depth. m10: humerus least width of shaft (measured slightly oblique to the plane of the bone). A. rufa extremes from Brodkorb and Mourer-Chauviré 1982. A. rufa/melanogaster extremes include data from Becker 1986 and Ballmann 1987. A. anhinga extremes include data from Rich 1972, Brodkorb and Mourer-Chauviré 1982, and Ballmann 1987.

\begin{tabular}{|c|c|c|c|c|c|c|c|c|c|c|}
\hline & m1 & m2 & m3 & m4 & m5 & m6 & m7 & m8 & m9 & m10 \\
\hline AUH 1489 & & & & & & 121.9 & 18.7 & 12.7 & 11.35 & 6.5 \\
\hline $\begin{array}{l}\text { Ruwais specimen (field } \\
\text { no. 'ADIAS 1421') }\end{array}$ & & & & & & & & 11.7 & 11.5 & \\
\hline AUH 1796 & & & $x ; \underline{6.95}$ & & & & & & & \\
\hline AUH 1319 & & & $8.35 ; \underline{x}$ & 8.5 & 7.0 & & & & & \\
\hline AUH 1592 & & & $9.0 \mathrm{e} ; \underline{\mathrm{x}}$ & & & & & & & \\
\hline AUH 1287 & 16.5 & 5.0 & & & & & & & & \\
\hline AUH 1113 & 15.5 & 4.3 & & & & & & & & \\
\hline $\begin{array}{l}\text { A. rufa BM } \\
\mathrm{S} / 1952.1 .87\end{array}$ & & & & & & & & 13.2 & 12.52 & 6.2 \\
\hline A. rufa IRSNB 12295 & 14.7 & & & & & 128.7 & 18.5 & 13.4 & & 6.0 \\
\hline A. rufa IRSNB 22452 & & & & & & 132.0 & 20.5 & 14.1 & & 6.9 \\
\hline A. rufa extremes & & & & $\begin{array}{l}9.5-9.8 \\
(\mathrm{n}=4)\end{array}$ & $\begin{array}{l}6.3-7.2 \\
(\mathrm{n}=4)\end{array}$ & & & & & \\
\hline $\begin{array}{l}\text { A. melanogaster } \\
\text { B. BM 1848.10.31.7 }\end{array}$ & 16.9 & $5.0 \mathrm{e}$ & $8.45 ; \underline{\mathrm{x}}$ & & & 141.2 & 20.8 & 13.6 & 12.56 & 6.8 \\
\hline $\begin{array}{l}\text { A. rufa/melanogaster } \\
\text { B. LAC } 1882.612\end{array}$ & & & & & & 135.4 & 19.1 & 13.0 & & 6.7 \\
\hline $\begin{array}{l}\text { A. rufa/melanogaster } \\
\text { B. LAC } 1886.176\end{array}$ & & & & & & 133.5 & 20.15 & 13.25 & & 6.8 \\
\hline $\begin{array}{l}\text { A. rufa/melanogaster } \\
\text { B. LAC } 1883.543\end{array}$ & & & & & & 133.1 & 18.8 & 13.75 & & 6.15 \\
\hline $\begin{array}{l}\text { A. rufa/melanogaster } \\
\text { LAC } 1884.193\end{array}$ & 17.4 & 6.2 & $10.0 ; \underline{9.0}$ & 9.7 & 6.4 & 137.0 & 20.0 & 13.3 & 11.0 & 6.9 \\
\hline $\begin{array}{l}\text { A. rufa/melanogaster } \\
\text { extremes }\end{array}$ & & & & & & $\begin{array}{l}128.7-142.0 \\
(\mathrm{n}=11)\end{array}$ & $\begin{array}{l}18.1-21.6 \\
(\mathrm{n}=19)\end{array}$ & & & \\
\hline A. anhinga PB 22871 & 16.0 & 5.15 & $9.0 ; 7.4$ & 7.9 & 6.3 & 127.5 & 17.75 & 13.5 & 9.9 & 5.7 \\
\hline $\begin{array}{l}\text { A. anhinga } \\
\text { BM 1896.2.16.17 }\end{array}$ & 16.5 & 5.9 & $8.25 ; \underline{x}$ & & & 124.05 & 18.7 & 12.46 & 11.3 & 5.85 \\
\hline
\end{tabular}


A. anhinga

BM S/1974.11.1

A. anhinga

LAC 1934.541

$121.5 \mathrm{e}$

18.5

13.2

6.0

A. anhinga extremes

7.9-9.5 6.1-7.1 $120.0-135.0$

Fossil A. hadarensis

$(\mathrm{n}=8) \quad(\mathrm{n}=8) \quad(\mathrm{n}=15)$

$9.1 \quad 6.3$

Table 9.3. Occurrences of the avian families in the late Miocene African localities that yielded bird fossils, site by site. Families in bold are those also found in the late Miocene of Abu Dhabi (present study). Data from Rich (1972, 1974), Ballmann (1987), Harris and Leakey (2003), Harris et al. (2003), Louchart et al. (2004, 2008), Pickford et al. (2009).

\begin{tabular}{|c|c|c|c|}
\hline Ecology & Family & Region & Sites, countries \\
\hline $\begin{array}{l}\text { aquatic, herbivorous } \\
\text { (surface ducks, swans, } \\
\text { geese) }\end{array}$ & Anatidae & $\mathrm{N}, \mathrm{E}$ Africa & $\begin{array}{l}\text { TM90, TM112, TM242, TM337 (Toros Menalla, } \\
\text { Chad); Sahabi (Libya); Lothagam (Kenya); ALA2 } \\
\text { (Ethiopia) }\end{array}$ \\
\hline aquatic, piscivorous & Anhingidae & $\mathrm{N}, \mathrm{E}$ Africa & $\begin{array}{l}\text { TM90, TM266 (Toros Menalla, Chad); Ngorora, } \\
\text { Lothagam (Kenya); Sahabi (Libya); Bled ed } \\
\text { Douarah (Tunisia); ASK3, DID1 (Ethiopia) }\end{array}$ \\
\hline $\begin{array}{l}\text { aquatic, mainly } \\
\text { piscivorous }\end{array}$ & Ardeidae & $\mathrm{N}, \mathrm{NE}$ Africa & $\begin{array}{l}\text { TM90 (Chad); ALA2 (Ethiopia); Bled ed Douarah } \\
\text { (Tunisia) }\end{array}$ \\
\hline $\begin{array}{l}\text { aquatic, piscivorous- } \\
\text { carnivorous }\end{array}$ & Balaenicipitidae & $\mathrm{N}$ Africa & Bled ed Douarah (Tunisia) \\
\hline $\begin{array}{l}\text { aquatic, piscivorous- } \\
\text { carnivorous }\end{array}$ & Ciconiidae & $\mathrm{N}, \mathrm{E}$ Africa & $\begin{array}{l}\text { TM90, TM266 (Chad); Bled ed Douarah } \\
\text { (Tunisia); Lothagam, Kanapoi (Kenya); }\end{array}$ \\
\hline $\begin{array}{l}\text { mainly aquatic, } \\
\text { omnivorous }\end{array}$ & Gruidae & $\mathrm{N}$ Africa & TM89 (Chad) \\
\hline $\begin{array}{l}\text { aquatic, piscivorous- } \\
\text { carnivorous }\end{array}$ & Heliornithidae & $\mathrm{N}$ Africa & TM90 (Chad) \\
\hline terrestrial, herbivorous & Otididae & E Africa & Lothagam (Kenya) \\
\hline aquatic, piscivorous & Pandionidae & NE Africa & DID1 (Ethiopia) \\
\hline aquatic, piscivorous & Pelecanidae & $\mathrm{N}, \mathrm{E}$ Africa & Sahabi (Libya); Lothagam (Kenya) \\
\hline aquatic, piscivorous & Phalacrocoracidae & N, NE Africa & $\begin{array}{l}\text { Bled ed Douarah (Tunisia); Sahabi (Libya); } \\
\text { STD1,2, ADD1, AFD1, ASK3, DID1 (Ethiopia); }\end{array}$ \\
\hline terrestrial, herbivorous & Phasianidae & NE Africa & ALA2 (Ethiopia) \\
\hline
\end{tabular}


aquatic, piscivorouscarnivorous

aquatic, piscivorous terrestrial, herbivorous
Phoenicopteridae

Podicipedidae

Struthionidae (bones N Africa only)

S Africa
Etosha Pan (Namibia)

STD2 (Ethiopia)

Garet el Maluk, Wadi Natrun (Egypt); Bled ed Douarah (Tunisia) 


\section{Figure Captions}

Figure 9.1. Map of Baynunah Formation localities from which avian remains have been recovered.

Figure 9.2. AUH 1134, pelvis of Struthio karatheodoris. Abbreviations: PV, pelvic vertebrae; SV sacral vertebrae; tp, transverse process; tub, tuberosity; cran, cranial; dors, dorsal; proc, process; proj, projection; vent, ventral; antitroch, antitrochanter; supratroch, supratrochanter; $20 \mathrm{~cm}$ scale bar is for ventral and right lateral views. $10 \mathrm{~cm}$ scale bar is for the cranial view of PV1. Other views either have a scale bar in the image itself, or are not to scale.

Figure 9.3. Fossil ratite eggshells. A, Diamantornis laini, AUH 1605. B, Aepyornithoid type, AUH 1773. Scale bars are in $\mathrm{cm}$.

Figure 9.4. SEM image of cross-section of Diamantornis laini eggshell, specimen YPM (Yale Peabody Museum) 56715. A, entire cross-section showing continuous and poorly delimited mammilary (1), spongy (2), and external (3) zones. External surface is to the top. B, close-up of a part of the mammilary zone.

Figure 9.5. A dense concentration of D. laini eggshell at RAQ 2, possibly a nest site, before (A) and after (B) disturbance.

Figure 9.6. Neognath bird fossils. A-E, Anhinga sp., cf. A. hadarensis. F, Phalacrocorax sp., cf. $P$. (P.) fuscicollis. A, left coracoid humeral end fragment, AUH 1592, in medial and lateral views. B, left coracoid humeral end, AUH 1319, in medio-dorsal, ventral, and lateral views. C, proximal right scapula, AUH 1113, in medial and lateral views. D, proximal right scapula, AUH 1287, in medial and lateral views. E, shaft fragment of right humerus, AUH 1722, in cranial and caudal views. F, proximal left carpometacarpus, AUH 1106, in dorsal and ventral views. Scale bars, $10 \mathrm{~mm}$. 
Figure 9.7. Neognath bird fossils. A, Anhinga sp., cf. A. hadarensis, left humerus, AUH 1489, in cranial, caudal, ventral and cranio-ventral views. B, Phalacrocorax sp., cf. $P$. (P.) fuscicollis, proximal right humerus fragment, AUH 1104, in caudal (top) and cranial (bottom) views. C, Nycticoracini gen. et sp. indet., left coracoid in two parts, AUH 1496; humeral and sternal parts are viewed from slightly different aspects for convenience of photography: in medial and lateral views (humeral part), and dorsal and ventral views (sternal part). Scale bars, $10 \mathrm{~mm}$. 
Fig 9.1

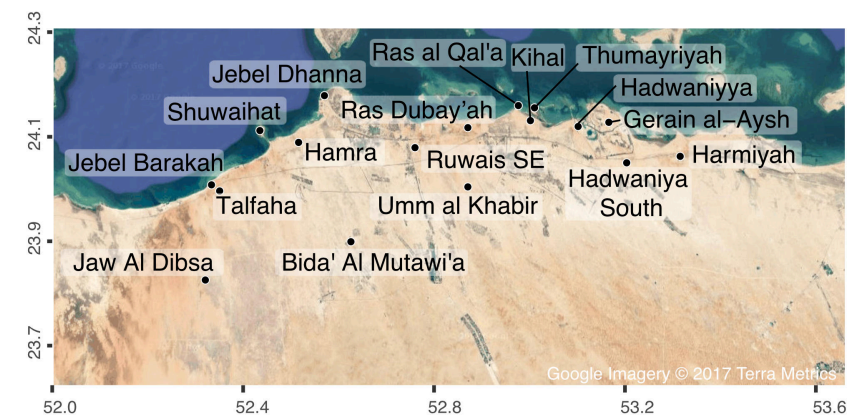




\section{Ventral View}

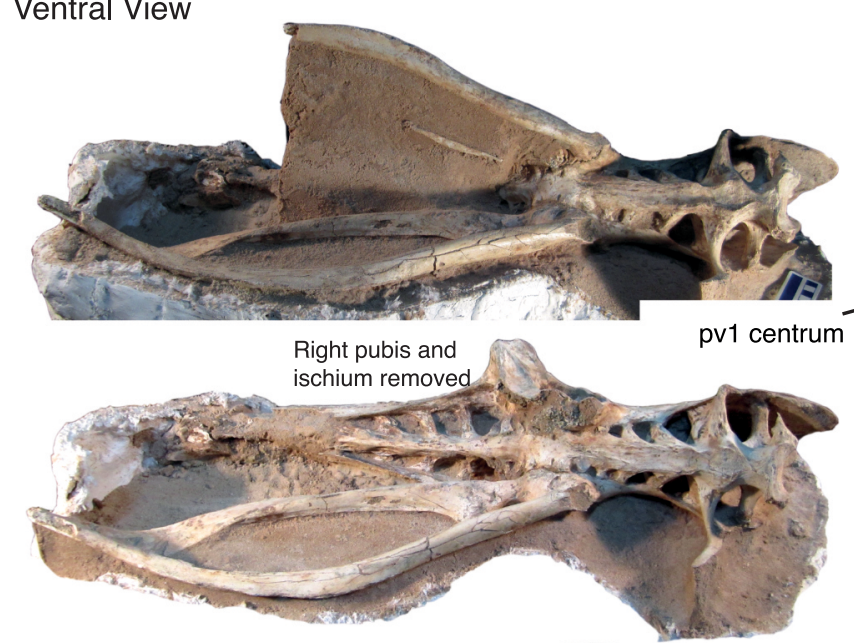

Cranial View of PV1

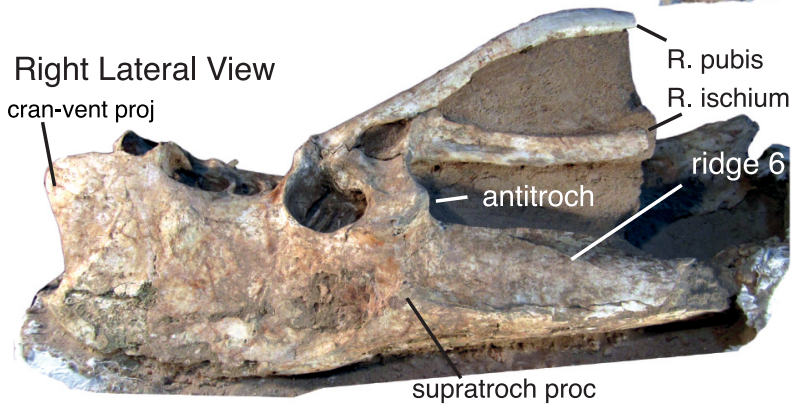

$20 \mathrm{~cm}$

cran-vent proj
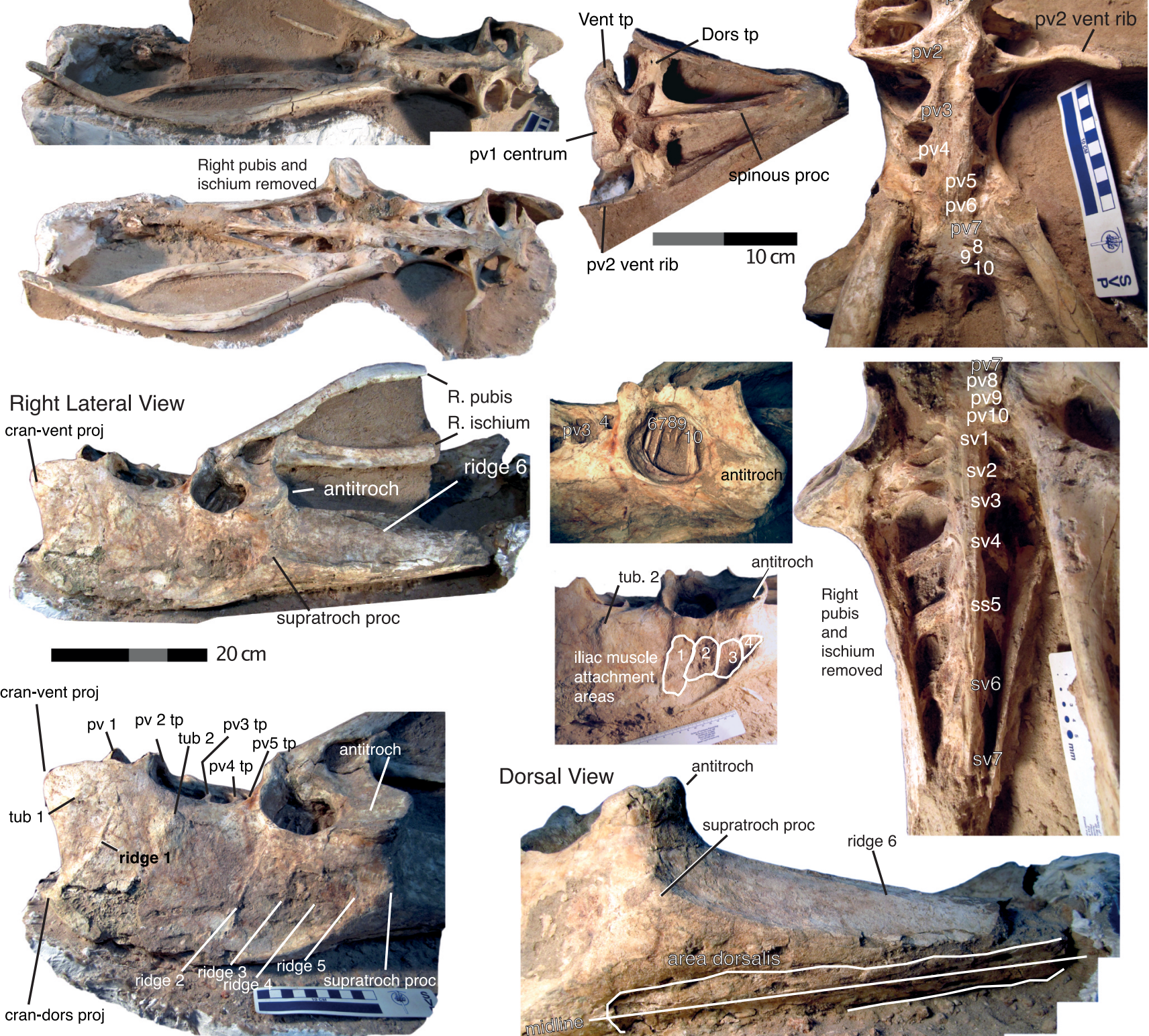

Ventral View

supratroch proc

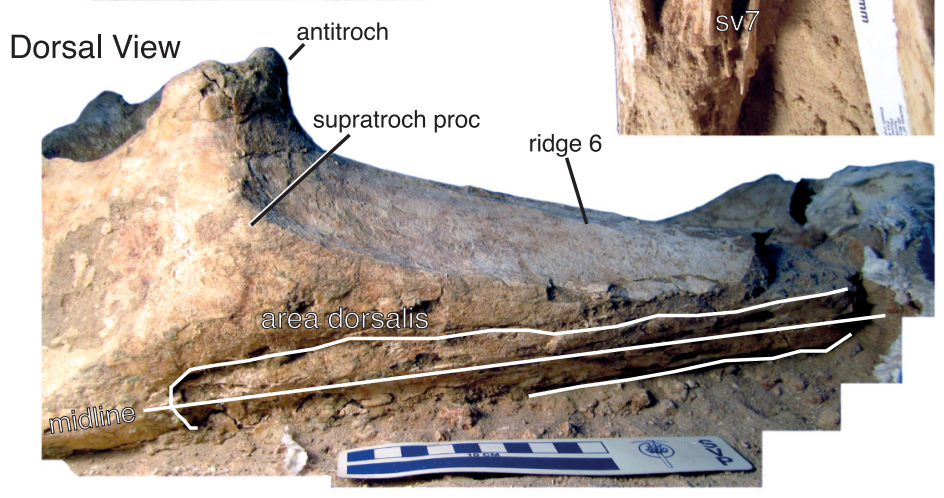

Fig 9.2 
Fig 9.3

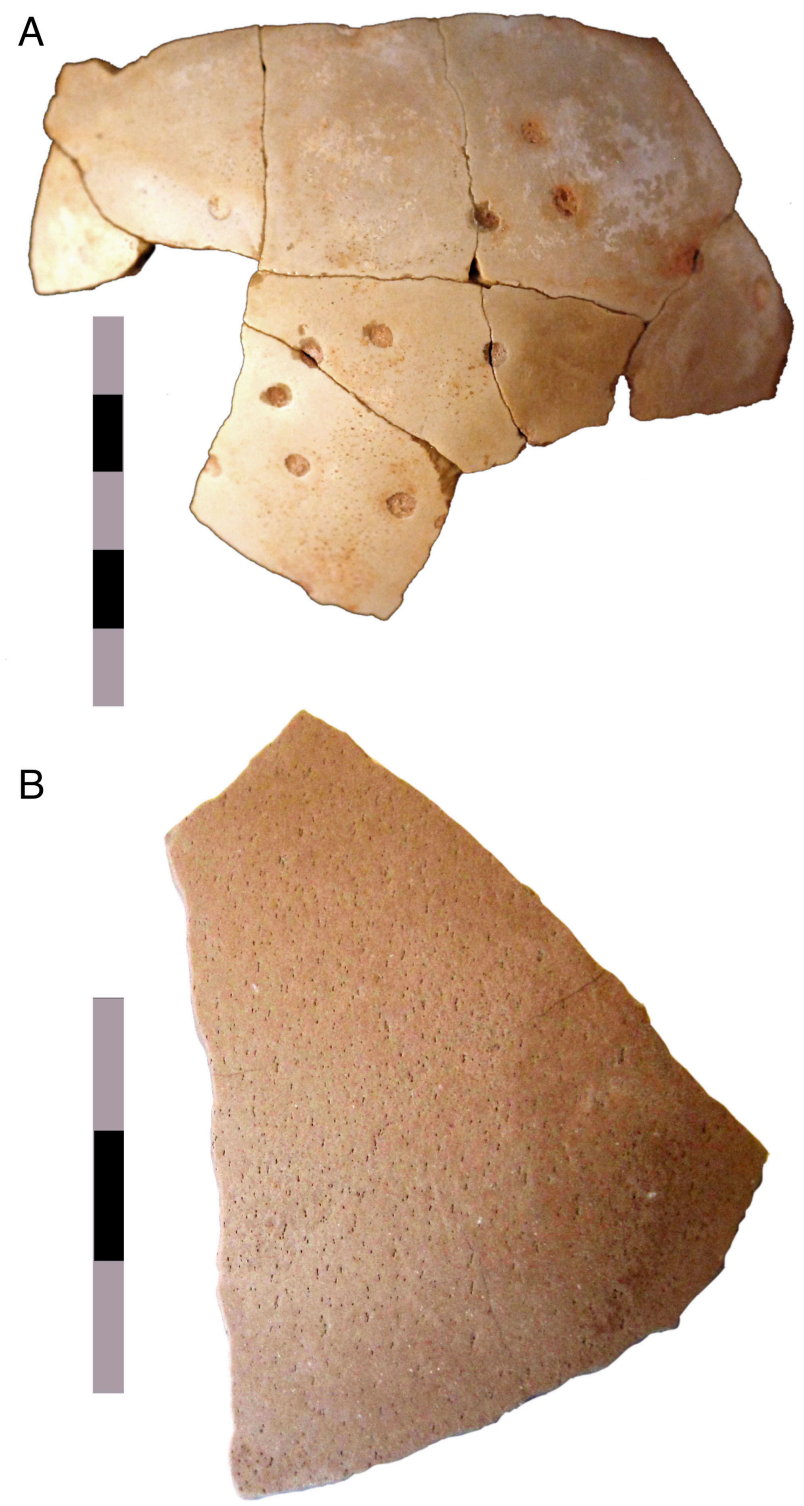


Fig 9.4

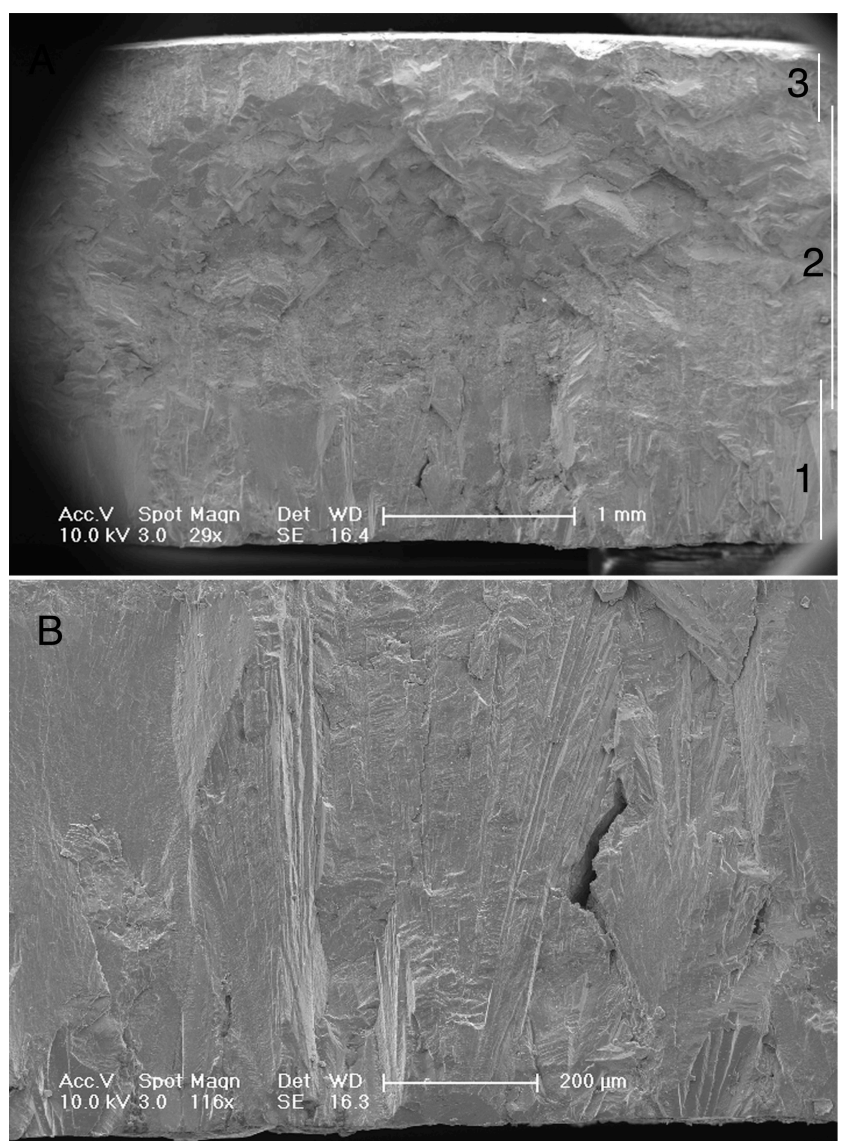


Fig 9.5

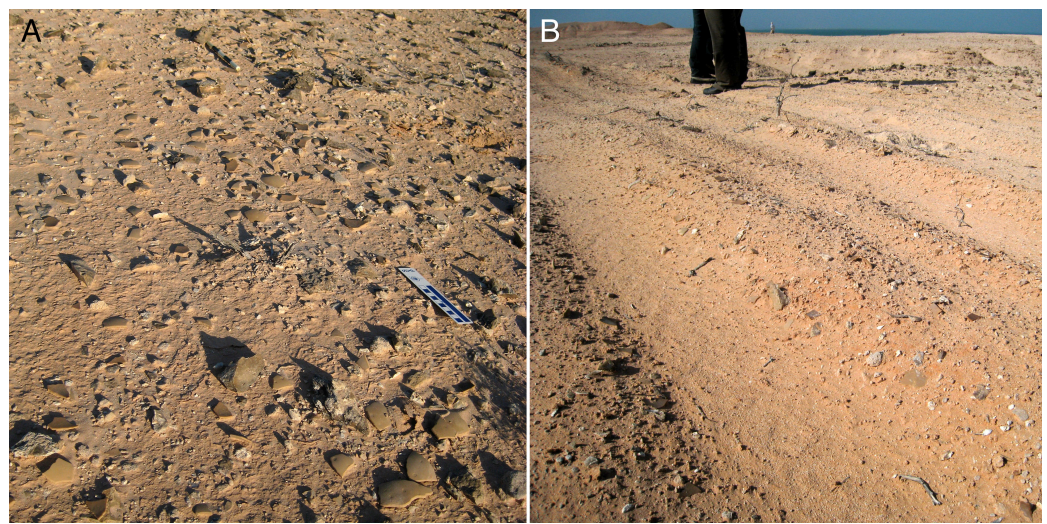


Fig 9.6
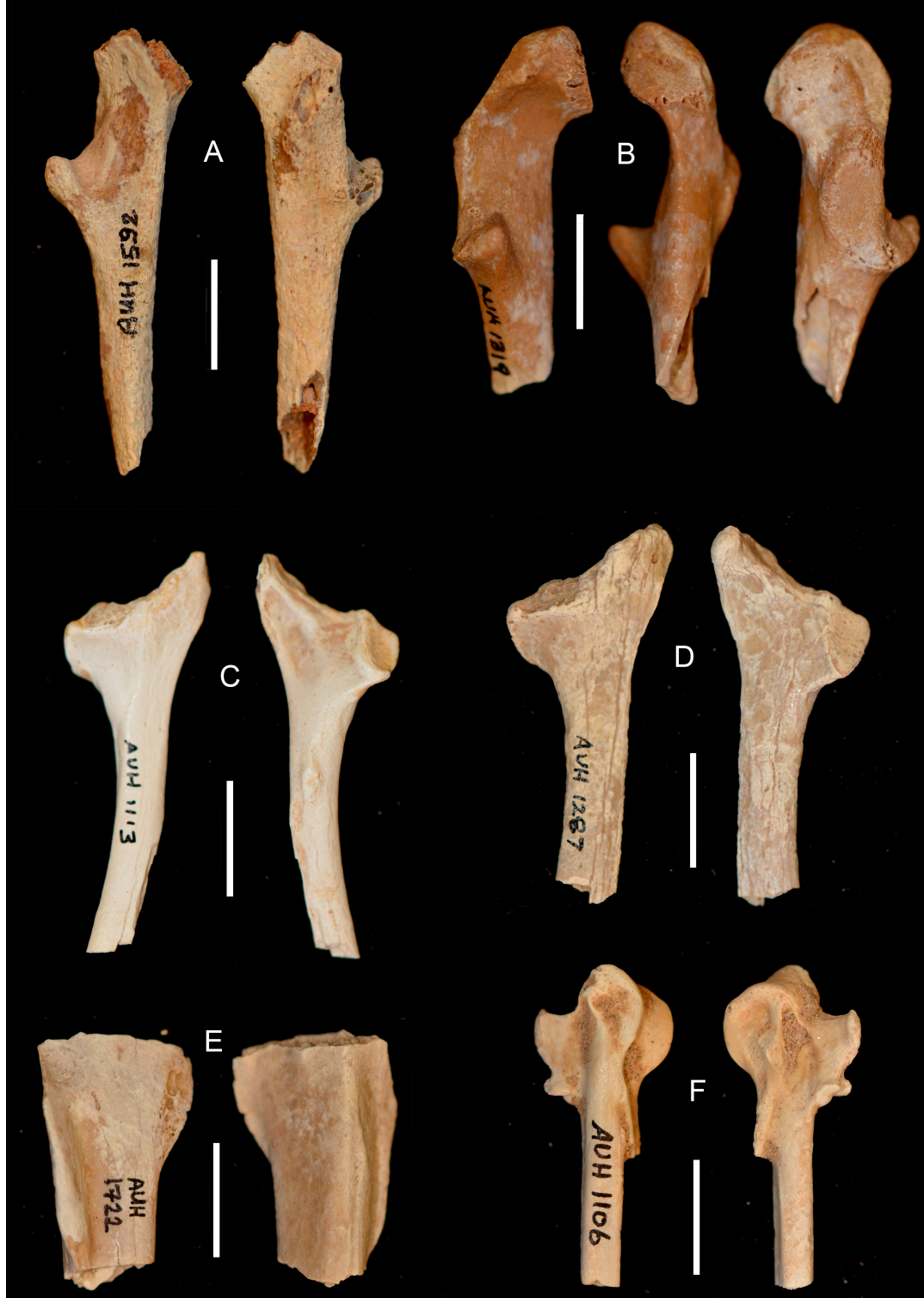
Fig 9.7

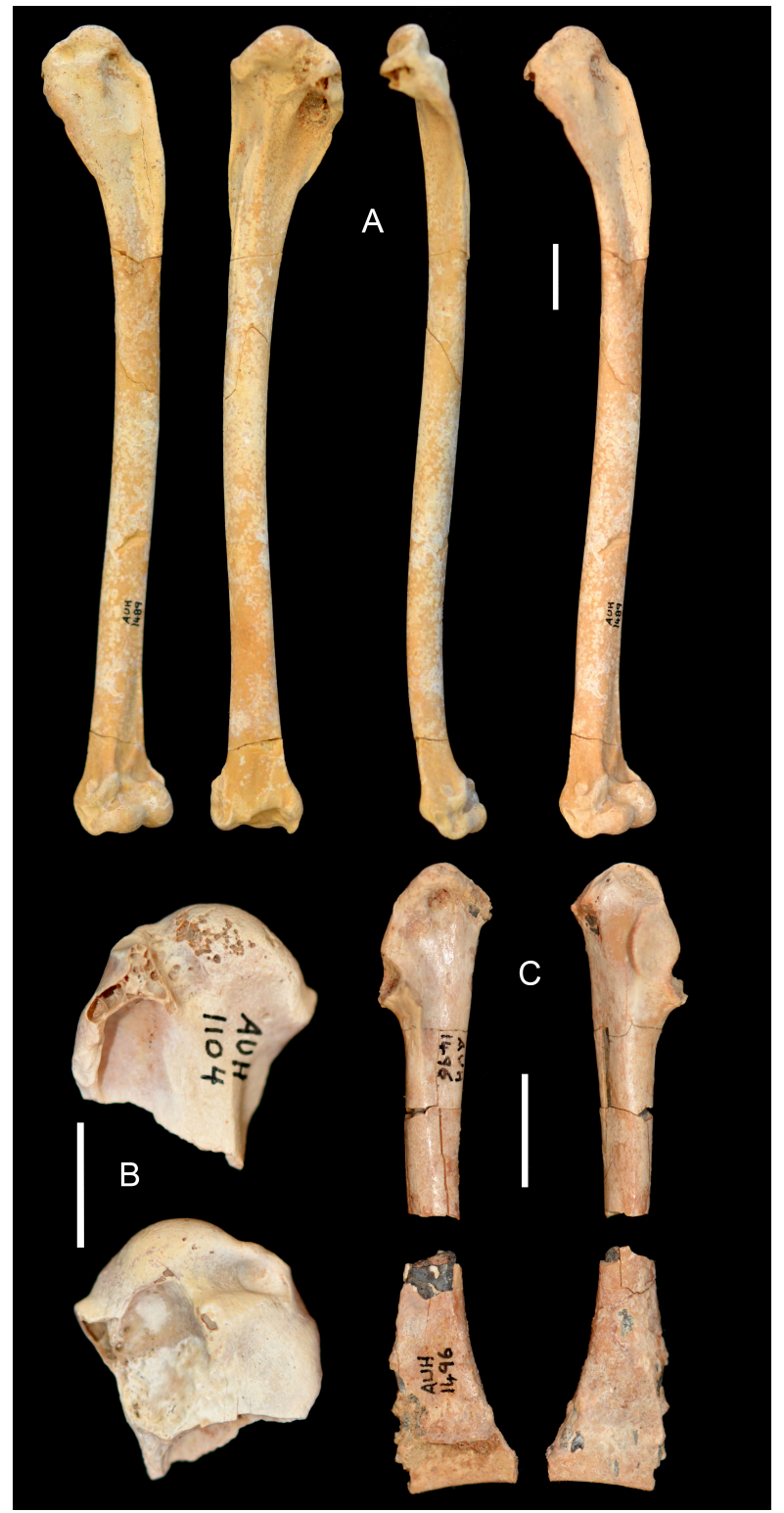

